\title{
EFFECT OF LINALOOL AND PIPERINE ON CHICKEN MEAT QUALITY DURING REFRIGERATED CONDITIONS
}

\author{
K.N. Hussein ${ }^{\mathrm{a}, \mathrm{b} *}$, L. Friedrich ${ }^{\mathrm{a}}$, R. Pinter ${ }^{\mathrm{a}}$, Cs. NÉMETH ${ }^{\mathrm{d}}$, G. KisKóc $^{\mathrm{c}}$ and I. DALMAdi ${ }^{\mathrm{a}}$ \\ ${ }^{a}$ Department of Refrigeration and Livestock Products Technology, Faculty of Food Science, Szent István \\ University, H-1118 Budapest, Ménesi út 43-45. Hungary \\ ${ }^{\mathrm{b}}$ Department of Animal Production, College of Agriculture, University of Duhok, Zakho Street 38, 42001 Duhok, \\ Kurdistan Region. Iraq \\ ${ }^{\mathrm{c}}$ Department of Microbiology and Biotechnology, Faculty of Food Science, Szent István University, H-1118 \\ Budapest, Somlói út 14-16. Hungary \\ ${ }^{\mathrm{d} C a p r i o v u s ~ L t d ., ~ H-2307 ~ S z i g e t c s e ́ p, ~ D u n a s o r ~ 073 / 72 ~ h r s z . ~ H u n g a r y ~}$
}

(Received: 20 January 2019; accepted: 17 June 2019)

\begin{abstract}
This study was conducted to evaluate the effect of bioactive compounds (BACs): linalool (LIN) and piperine (PIP) on chicken meat characteristics. The meat was treated with $500,1000 \mathrm{ppm}$ of BACs, vacuum packaged and stored at $4{ }^{\circ} \mathrm{C}$ for 8 days. Physicochemical characteristics, lipid oxidation (thiobarbituric acid reactive substances, TBARS), microbiological status, and sensorial (electronic-nose based) properties were investigated. Both BACs significantly increased the redness $\left(a^{*}\right)$ and chroma $\left(C^{*}\right)$ values in meat compared to increased lightness $\left(L^{*}\right)$ and higher TBARS in control. Although both BACs showed overlapping aroma profile, the E-nose was able to distinguish between the different meat groups. LIN with various dilution ratios, particularly 1:10 (v:v), showed in vitro growth inhibition against Escherichia coli, Staphylococcus aureus, Salmonella Typhimurium, and Bacillus cereus, concomitantly Listeria monocytogenes required 1:80 (v:v) to be inhibited, and no inhibition was detected for Pseudomonas lundensis. In contrast, PIP at different dilutions did not exhibit inhibitory activity. Regarding aerobic mesophilic counts (AMC), less than $7 \log \mathrm{CFU} \mathrm{g}^{-1}$ were recorded except for control showing higher log. Both BACs have potential to improve quality characteristics and increase the shelf life of meat and meat products.
\end{abstract}

Keywords: bioactive compounds, chicken meat, antimicrobial, lipid oxidation, physicochemical characteristics

The application of bioactive compounds (BACs) and essential oils (Eos) is gaining a wide interest as alternatives to conventionally used preservatives and synthetic food additives. Various EOs as natural derivatives (rosemary, thyme, mustard, oregano, and cinnamon) and natural phenolic, non-phenolic BACs (carvacrol, thymol, $p$-cymene, allyl isothiocyanate, cinnamaldehyde, and eugenol) have been applied for the prevention of foodborne illnesses and retarding the deterioration of food products (JRIDI et al., 2015; PIÑON et al., 2015; ROKAITYTE et al., 2016). BACs can intensify healthier manufacture, however, only low concentrations of BACs can be applied in meat preservation, due to characteristic flavour properties. Many EOs and their BACs are considered GRAS and legalized to be applied in different food systems. Furthermore, they are approved by the Food and Drug Administration (FDA) and European Commission (2002/113/EC, 2002) regulations as flavourings and food additives (PREEDY, 2015).

Poultry meat is highly vulnerable to quality changes throughout the miscellaneous stages of preparation, storage, and distribution. Consequently, if meat is not preserved

\footnotetext{
* To whom correspondence should be addressed.

Phone: +36 30 6468163; e-mail: khabat.noori@uod.ac
} 
properly, it could be common vehicle for food-borne illnesses (microbial contamination), lipid oxidation, sensorial changes (soft and exudative-texture, off-flavour/odour, discolouration), and compromise nutritional quality of meat products (JRIDI et al., 2015; PIÑON et al., 2015). These product quality concerns can be avoided using the EOs and their BACs as natural flavouring agents and food-preservatives. Several studies can be seen on extending the shelf-life of foods using BACs with the focus on certain assessments including antimicrobial activity, antifungal properties, anti-inflammatory, and anticancer activities (PATtNaik et al., 1997; Dorman \& DeAns, 2000; PeAna et al., 2002; Jridi et al., 2015). Linalool (LIN) is an acyclic monoterpene alcohol, which constitutes approximately $69 \%$ of basil (Ocimum basilicum) composition (KÉITA et al., 2000). Piperine (PIP), the major alkaloid BAC that accounts for up to $9 \%$ of black pepper, is responsible for the aroma of pepper and exhibits sedating, detoxification, hypotensive, and anticarcinogenic properties (GORGANI et al., 2017). Additionally, it has been reported that these BACs exhibit antifungal (PATTNAIK et al., 1997), anti-inflammatory, anticancer (PEANA et al., 2002), and hydroxyl radical scavenger activities in in vitro and animal models (MitTAL \& GUPTA, 2000). However, to our knowledge, no studies have been devoted to the putative physicochemical, antioxidant, antimicrobial, and sensory (E-nose) based effects of LIN and PIP on chicken meat, although both BACs are commonly used as antimicrobials in vitro in many studies.

\section{Materials and methods}

\subsection{Preparation of meat samples}

Fresh chicken breast meat, 24 hours post-mortem, were obtained from a local abattoir and transported to the laboratories. Meat was minced, then homogenized and divided into treatment groups: groups mixed with 500 and $1000 \mathrm{ppm}$ linalool and piperine (dissolved in $5 \%$ sunflower oil) and control (only sunflower oil). Both LIN ( $>97 \%)$ and PIP ( $\geq 97 \%)$ were obtained from SIGMA (Germany). The samples were then placed in polyethylene bags, vacuum packaged, stored at $4 \pm 0.5^{\circ} \mathrm{C}$, and analysed on days $1,3,6$, and 8 of storage.

\subsection{Methods and measurements}

1.2.1. Physicochemical properties and determination of TBARS. The $\mathrm{pH}$ of meat was determined in triplicate by immersing a $\mathrm{pH}$ electrode (Testo 206- Testo-AG Germany). The CIELAB values: $L^{*}$ (lightness), $a^{*}$ (redness), and $b^{*}$ (yellowness) were measured at 5 different locations along the pouches using a Konica Minolta CR-400 colourimeter (Konica Minolta Sensing Inc., Japan). Results from $L^{*}, a^{*}$, and $b^{*}$ were recorded as the mean of measurements, and from the measured values relative colourfulness or chroma magnitude $\left(C^{*}\right)$ and hue angle $\left(h^{*}\right)$ were calculated as the following:

$$
\text { Chroma: } C^{*}=\left\{a^{* 2}+b^{* 2}\right\}^{1 / 2} \text {, hue angle: } h^{*}=\tan ^{-1}\left\{b^{*} / a^{*}\right\}
$$

Lipid oxidation was measured by analysing TBARS using the method described by TARLADGIS and co-workers (1960). TBARS were expressed as mg malonaldehyde (MDA equivalent) /1000 g sample. 
1.2.2. In vitro anti-microbial activity of BACs (Agar well diffusion assay). BACs were prepared as mixture of BACs and sunflower oil in various ratios (v/v) (Table 1) prior to their application according to the modified method by Dorman and DEAns (2000). Three Grampositive (L. monocytogenes CCM 4699, St. aureus ATCC 6538, and B. cereus T1) and three Gram-negative (E. coli O157:H7 BO1909, S. Typhimurium (B1310), and P. lundensis (CCP5)) strains were used as target bacteria. Each strain was grown on Tryptic-Soy agar (TSA, Biokar Diagnostics BK046HA) at $37{ }^{\circ} \mathrm{C}$ for $24 \mathrm{~h}$ except $P$. lundensis, that was grown at $25{ }^{\circ} \mathrm{C}$. The culture suspension was adjusted to 0.5 optical density (OD) by using a densitometer (DEN-1B, McFarland), and the density of the working culture was set to approximately $10^{6} \mathrm{CFU} \mathrm{m}{ }^{-1}$. The wells of $8 \mathrm{~mm}$ in diameter were filled with $100 \mu \mathrm{l}$ of the appropriate dilution of the BACs. Sterile water was pipetted into the holes in case of control. After 24, 48, and $72 \mathrm{~h}$ of storage, zones of growth inhibition ( $\mathrm{mm}$ ) were measured using a digital Vernier calliper (Workzone-calliper).

Table 1. Serial dilutions of BACs used for the in vitro antimicrobial measurement

\begin{tabular}{lc}
\hline Dilution ratio (v:v) & BACs $\mathrm{mg} / 5 \mathrm{~g}$ oil \\
\hline $1: 640$ & 7.81 \\
$1: 320$ & 15.62 \\
$1: 158$ & 31.25 \\
$1: 80$ & 62.5 \\
$1: 40$ & 125 \\
$1: 20$ & 250 \\
$1: 16$ & 312.5 \\
$1: 10$ & 500 \\
$1: 8$ & 625 \\
$1: 4$ & 1250 \\
$1: 2$ & 2500 \\
\hline
\end{tabular}

1.2.3. Microbiological analysis of meat. Microbiological analysis of chicken meat was carried out with the method applied by JRIDI and co-workers (2015). The results of AMC were given as logarithms of colony-forming units per gram of sample $\left(\log \mathrm{CFU} \mathrm{g}^{-1}\right)$.

1.2.4. Electronic nose analysis. Electronic nose measurements were performed with an NST 3320 instrument (Applied Sensor, Linköping, Sweden) as described by FrIEDRICH and co-workers (2008). Difference of sensor signals between the baseline and the signal value at the end of the sampling time was used for multivariate statistical analysis (canonical discriminant analysis, CDA) as sensor response.

\subsection{Statistical analysis}

Data were analysed using SPSS (Version 23.0, SPSS Inc.). The data were subjected to analysis of variance (ANOVA) and General Linear Model, then level of significance was established using Tukey's test at $(\mathrm{P}<0.05)$. 


\section{Results and discussion}

\subsection{Physicochemical properties and TBARS}

The results of physicochemical properties are presented in Table 2. LIN showed activity towards maintaining the $\mathrm{pH}$, while PIP had more activity in reducing $\mathrm{pH}$ values of the meat, and both had higher $\mathrm{pH}$ than control group at the end of storage. Decrease of $\mathrm{pH}$ with PIP may be attributed to the inhibitory effect of BACs on the growth and proliferation of spoilage microorganisms that metabolize basic nitrogen compounds.

Table 2. Effect of different concentrations of LIN and PIP on physicochemical properties and TBARS of fresh chicken meat stored for 8 days at $4{ }^{\circ} \mathrm{C}$

\begin{tabular}{|c|c|c|c|c|c|c|}
\hline \multirow[t]{2}{*}{ Parameters } & \multirow{2}{*}{$\begin{array}{l}\text { Storage } \\
\text { time }(d)\end{array}$} & \multicolumn{5}{|c|}{ Active compounds } \\
\hline & & No-BAC & LIN-500 ppm & LIN-1000 ppm & PIP-500 ppm & PIP-1000 ppm \\
\hline \multirow[t]{4}{*}{$\mathrm{pH}$} & 1 & $5.89 \pm 0.02^{\mathrm{bA}}$ & $5.93 \pm 0.01^{\mathrm{bB}}$ & $5.91 \pm 0.01^{\mathrm{cAB}}$ & $5.91 \pm 0.01^{\mathrm{cA}}$ & $5.89 \pm 0.01^{\mathrm{cA}}$ \\
\hline & 3 & $5.93 \pm 0.01^{\mathrm{cA}}$ & $5.98 \pm 0.01^{\mathrm{cB}}$ & $5.98 \pm 0.01 \mathrm{~dB}$ & $5.95 \pm 0.01 \mathrm{dA}$ & $5.96 \pm 0.01 \mathrm{dA}$ \\
\hline & 6 & $5.78 \pm 0.01^{\mathrm{aA}}$ & $5.81 \pm 0.01^{\mathrm{aB}}$ & $5.83 \pm 0.01^{\mathrm{bC}}$ & $5.70 \pm 0.02^{\mathrm{aA}}$ & $5.71 \pm 0.02^{\mathrm{aB}}$ \\
\hline & 8 & $5.76 \pm 0.01^{\mathrm{aA}}$ & $5.79 \pm 0.01^{\mathrm{aA}}$ & $5.80 \pm 0.02^{\mathrm{aA}}$ & $5.78 \pm 0.01^{\mathrm{bA}}$ & $5.77 \pm 0.02^{\mathrm{bA}}$ \\
\hline \multirow[t]{4}{*}{$L^{*}$} & 1 & $49.23 \pm 0.29^{\mathrm{aA}}$ & $48.41 \pm 0.38^{\mathrm{aB}}$ & $48.30 \pm 0.42^{\mathrm{aB}}$ & $48.47 \pm 0.80^{\mathrm{aA}}$ & $49.15 \pm 0.81^{\mathrm{aA}}$ \\
\hline & 3 & $51.40 \pm 0.29^{\mathrm{bA}}$ & $51.07 \pm 1.09^{\mathrm{bA}}$ & $50.48 \pm 0.11^{\mathrm{bA}}$ & $50.79 \pm 0.24^{\mathrm{bA}}$ & $50.76 \pm 0.56^{\mathrm{bA}}$ \\
\hline & 6 & $53.47 \pm 0.38^{\mathrm{cA}}$ & $51.95 \pm 0.42^{\mathrm{bB}}$ & $51.72 \pm 0.45^{\mathrm{cB}}$ & $52.58 \pm 0.28^{\mathrm{cA}}$ & $53.01 \pm 0.89^{\mathrm{cA}}$ \\
\hline & 8 & $52.70 \pm 0.42^{\mathrm{cA}}$ & $50.89 \pm 0.55^{\mathrm{bB}}$ & $50.50 \pm 0.62^{\mathrm{bB}}$ & $51.40 \pm 0.78^{\mathrm{bA}}$ & $51.9 \pm 0.32^{\mathrm{bAB}}$ \\
\hline \multirow[t]{4}{*}{$a^{*}$} & 1 & $3.84 \pm 0.77^{\mathrm{aA}}$ & $4.31 \pm 0.58^{\mathrm{aA}}$ & $4.07 \pm 0.22^{\mathrm{aA}}$ & $4.32 \pm 0.34^{\mathrm{aA}}$ & $4.16 \pm 0.30^{\mathrm{aA}}$ \\
\hline & 3 & $4.66 \pm 0.62^{\mathrm{aA}}$ & $4.64 \pm 0.28^{\mathrm{aA}}$ & $4.50 \pm 0.38^{\mathrm{abA}}$ & $4.65 \pm 0.15^{\mathrm{abA}}$ & $5.00 \pm 0.36^{\mathrm{bA}}$ \\
\hline & 6 & $4.57 \pm 0.18^{\mathrm{aA}}$ & $5.18 \pm 0.50^{\mathrm{aB}}$ & $5.27 \pm 0.24^{\mathrm{cB}}$ & $4.95 \pm 0.60^{\mathrm{abA}}$ & $5.20 \pm 0.30^{\mathrm{bA}}$ \\
\hline & 8 & $4.25 \pm 0.18^{\mathrm{aA}}$ & $5.09 \pm 0.55^{\mathrm{aB}}$ & $4.95 \pm 0.51^{\mathrm{bcA}}$ & $5.03 \pm 0.20^{\mathrm{bB}}$ & $5.19 \pm 0.41^{\mathrm{bB}}$ \\
\hline \multirow[t]{4}{*}{$b^{*}$} & 1 & $2.60 \pm 0.52^{\mathrm{aA}}$ & $2.36 \pm 0.58^{\mathrm{aA}}$ & $2.51 \pm 0.22^{\mathrm{aA}}$ & $2.78 \pm 0.09^{\mathrm{aA}}$ & $2.93 \pm 0.27^{\mathrm{aA}}$ \\
\hline & 3 & $2.34 \pm 0.35^{\mathrm{aA}}$ & $2.26 \pm 0.40^{\mathrm{aA}}$ & $2.57 \pm 0.37^{\mathrm{aA}}$ & $2.70 \pm 0.40^{\mathrm{aAB}}$ & $3.16 \pm 0.36^{\mathrm{abB}}$ \\
\hline & 6 & $2.58 \pm 0.42^{\mathrm{aA}}$ & $2.53 \pm 0.38^{\mathrm{aA}}$ & $2.56 \pm 0.29^{\mathrm{aA}}$ & $2.66 \pm 0.18^{\mathrm{aA}}$ & $3.23 \pm 0.33^{\mathrm{abB}}$ \\
\hline & 8 & $2.46 \pm 0.28^{\mathrm{aA}}$ & $2.60 \pm 0.31^{\mathrm{aA}}$ & $2.66 \pm 0.55^{\mathrm{aA}}$ & $3.07 \pm 0.36^{\mathrm{aAB}}$ & $3.95 \pm 0.96^{\mathrm{bB}}$ \\
\hline \multirow[t]{4}{*}{$C^{*}$} & 1 & $4.66 \pm 0.75^{\mathrm{aA}}$ & $4.94 \pm 0.63^{\mathrm{aA}}$ & $4.79 \pm 0.22^{\mathrm{aA}}$ & $5.14 \pm 0.30^{\mathrm{aA}}$ & $5.09 \pm 0.34^{\mathrm{aA}}$ \\
\hline & 3 & $5.24 \pm 0.43^{\mathrm{aA}}$ & $5.17 \pm 0.42^{\mathrm{aA}}$ & $5.19 \pm 0.49^{\mathrm{abA}}$ & $5.39 \pm 0.31^{\mathrm{ab} A B}$ & $5.93 \pm 0.34^{\mathrm{abB}}$ \\
\hline & 6 & $5.26 \pm 0.31^{\mathrm{aA}}$ & $5.78 \pm 0.50^{\mathrm{aA}}$ & $5.87 \pm 0.28^{\mathrm{bA}}$ & $5.63 \pm 0.54^{\mathrm{abAB}}$ & $6.13 \pm 0.24^{\mathrm{bB}}$ \\
\hline & 8 & $4.92 \pm 0.13^{\mathrm{aA}}$ & $5.72 \pm 0.58^{\mathrm{aB}}$ & $5.64 \pm 0.53^{\mathrm{bAB}}$ & $5.90 \pm 0.12^{\mathrm{bB}}$ & $6.55 \pm 0.85^{\mathrm{bB}}$ \\
\hline \multirow[t]{4}{*}{$h^{*}$} & 1 & $0.89 \pm 0.36^{\mathrm{aA}}$ & $0.62 \pm 0.19^{\mathrm{aA}}$ & $0.71 \pm 0.10^{\mathrm{aA}}$ & $0.75 \pm 0.09^{\mathrm{aA}}$ & $0.86 \pm 0.11^{\mathrm{aA}}$ \\
\hline & 3 & $0.58 \pm 0.18^{\mathrm{aA}}$ & $0.53 \pm 0.08^{\mathrm{aA}}$ & $0.64 \pm 0.07^{\mathrm{aA}}$ & $0.65 \pm 0.11^{\mathrm{aA}}$ & $0.74 \pm 0.14^{\mathrm{aA}}$ \\
\hline & 6 & $0.64 \pm 0.13^{\mathrm{aA}}$ & $0.53 \pm 0.11^{\mathrm{aA}}$ & $0.52 \pm 0.07^{\mathrm{aA}}$ & $0.60 \pm 0.10^{\mathrm{aA}}$ & $0.72 \pm 0.12^{\mathrm{aA}}$ \\
\hline & 8 & $0.66 \pm 0.13^{\mathrm{aA}}$ & $0.56 \pm 0.08^{\mathrm{aA}}$ & $0.61 \pm 0.19^{\mathrm{aA}}$ & $0.71 \pm 0.14^{\mathrm{aA}}$ & $0.97 \pm 0.29^{\mathrm{aA}}$ \\
\hline \multirow{2}{*}{$\begin{array}{l}\text { TBARS (mg } \\
\text { MDA/kg) }\end{array}$} & 1 & $1.43 \pm 0.12^{\mathrm{aA}}$ & $1.86 \pm 0.10^{\mathrm{aA}}$ & $1.78 \pm 0.22^{\mathrm{aA}}$ & $1.57 \pm 0.05^{\mathrm{aA}}$ & $2.65 \pm 0.54^{\mathrm{aA}}$ \\
\hline & 8 & $2.02 \pm 0.31^{\mathrm{aA}}$ & $1.55 \pm 0.01^{\mathrm{aA}}$ & $1.83 \pm 0.10^{\mathrm{aA}}$ & $1.91 \pm 0.04^{\mathrm{aA}}$ & $1.51 \pm 0.09^{\mathrm{aA}}$ \\
\hline
\end{tabular}

a,b,c: Means in same row with different superscript are significantly different regarding the days of storage.

A,B,C: Means in same column with different superscript are significantly different regarding the concentrations of BACs $(\mathrm{P}<0.05)$ 
The colour of chicken meat shows significant differences with intensifying drifts in lightness during the storage period (except day 3), however, less increasing trends were recorded in samples treated with BACs compared to control. Addition of LIN was effective in keeping the $L^{*}$ values close to the initial $L^{*}$ values. Increase in the $L^{*}$ value, particularly in control meat, refers to the paleness of meat, and may be due to an increase in oxidation, developing rancidity and influencing consumers' acceptability for the meat (KARABAGIAS et al., 2011). The $a^{*}$ values in meat containing LIN-500 ppm was significantly higher, however, this increase in the $a^{*}$ values were lower compared to the meat treated with $1000 \mathrm{ppm}$ of PIP. The $b^{*}$ value of the control decreased at day 8 of storage. Reverse trend with no significant difference was observed in meat treated with LIN. However, the meat containing PIP showed significantly higher $b^{*}$ compared to other groups (Table 2). Our results are in agreement with the findings of MARTínez and co-workers (2006), who observed that an increase in the concentrations of red-sweet, cayenne, and black pepper in pork sausages resulted in lower $L^{*}$ and significant increase in $a^{*}$ and $b^{*}$ values. Moreover, increasing trends of $C^{*}$ colour intensity were detected in all samples. On the other hand, decreasing rate of hue values $\left(h^{*}\right)$ was detected in all groups except PIP-1000 ppm with no significant differences. The current results of redness of meat appeared with inconsistent relationship with increase of $L^{*}$ and decrease in $b^{*}$. This resulted a decrease of $C^{*}$, particularly in control group, that could be due to gradual oxidation of myoglobin, building up metmyoglobin and developing discoloration of meat. Simultaneously, an increased $a^{*}$ value was perceived in meat treated with LIN and PIP, which has a great contribution towards the final colour intensity of the meat.

In the current study, at the end of storage, control group showed higher TBARS values compared to the rest of the samples, whereas the meat containing PIP-1000 ppm showed nonsignificant reduction in TBARS values $(\mathrm{P}<0.05)$ (Table 2). Our result was in accordance with the findings of MARTínEZ and co-workers (2006), who treated sausage with $0.5 \%$ of different types of pepper and noticed TBARS level of $1.5 \mathrm{mg} \mathrm{MDA} / \mathrm{kg}$ at day $10 \mathrm{of}$ storage compared to $6.5 \mathrm{mg} \mathrm{MDA} / \mathrm{kg}$ for control at the same day. BACs had a clear protective effect against lipid oxidation by keeping TBARS scores lower than $2 \mathrm{mg} \mathrm{MDA} / \mathrm{kg}$. This could be attributed to strong potential antioxidant activity of selected BACs, inhibiting the formation of secondary products of lipid oxidation that may contribute to the off-flavour in stored meat products.

\subsection{Evaluation of in-vitro antimicrobial activity of $B A C S$}

LIN with the ratio of 1:10 (v:v) during 24-72 h of storage exhibited inhibition zone for E. coli, St. aureus, S. Typhimurium, and B. cereus. While L. monocytogenes required 1:80 (v:v) LIN to show inhibition, concomitantly no inhibition was detected for P. lundensis (Table 3). Our results are in accordance with the work of DoRman and DEANs (2000) that showed in vitro activity of LIN and recorded inhibitory zone of $13.8 \pm 0.3, \mathrm{NI}, 7.5 \pm 0.5$, and $9.0 \pm 0.4 \mathrm{~mm}$ for E. coli, Pseudomonas spp., S. Pullorum, and St. aureus, respectively. In the current study LIN inhibited both food borne pathogenic and food spoilage bacteria. Thus, these data can obviously serve as well as confirmatory and complementary data for the previously published work. PIP at different concentrations did not exhibit inhibitory activity against the studied bacteria. This could be due to its poor solubility in aqueous and oily environments, which limits its biological applications (GorGani et al., 2017). SHIVARANi and co-workers (2013) used $100 \mu \mathrm{l}$ of PIP in vitro, and observed high susceptibility of Grampositive bacteria (St. aureus and B. subtilis) and less susceptibility of Gram-negative bacteria (Pseudomonas spp. and E. coli) to PIP. 


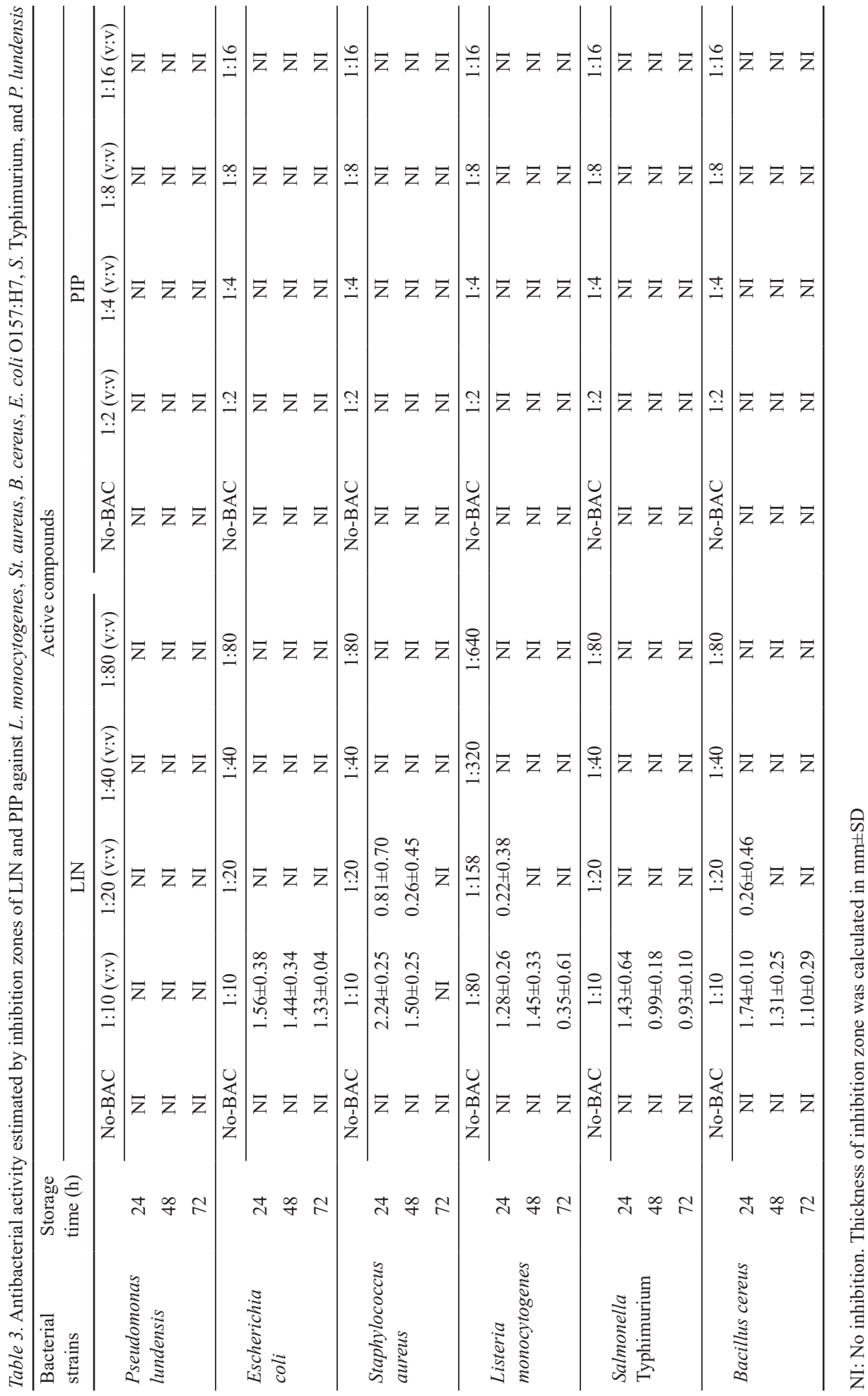




\subsection{Microbiological characteristics of meat}

The AMC showed nonsignificant differences between treated and untreated chicken meat throughout the storage period $(\mathrm{P}<0.05)$ (Fig. 1). It has been reported that TVC of $7 \log \mathrm{CFU} \mathrm{g}^{-1}$ is considered as the upper microbiological limit for acceptable meat quality (KARABAGIAS et al., 2011). Surprisingly, in contrast to current in vitro results, the effectiveness of PIP was higher than LIN, indicating a small prolongation of the lag phase of microbial growth. Comparable findings were highlighted by MARTínez and co-workers (2006), who observed lower values of psychrotrophic counts as they recorded 6.10 and $5.06 \log$ CFU g ${ }^{-1}$ for control and $1 \%$ black pepper at day 8 of storage, respectively. Poor solubility in aqueous media and reaction with constituents of meat may reduce the antimicrobial activity of BACs. No data on antimicrobial effect of LIN and PIP on chicken meat have been found in the literature thus far.

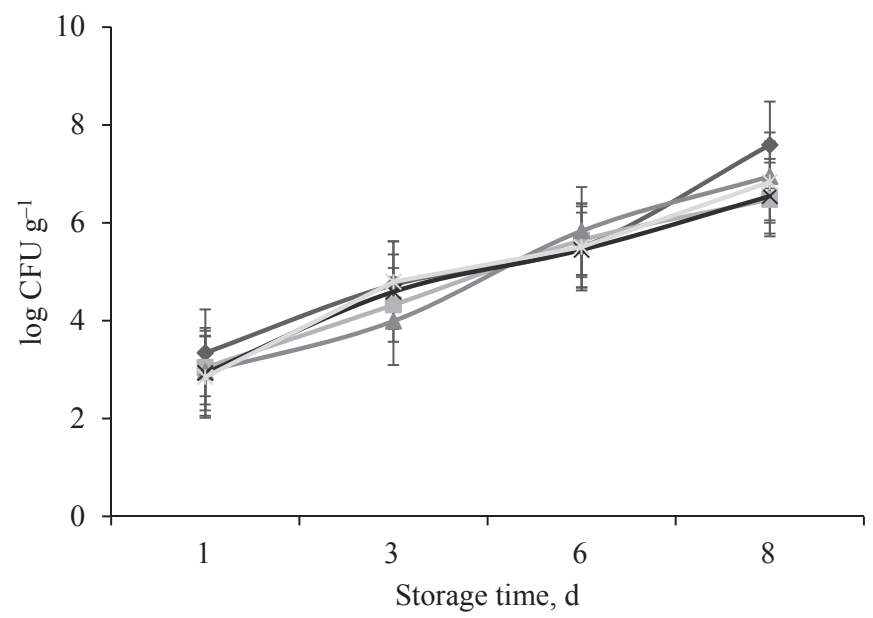

Fig. 1. Effect of different concentrations of LIN and PIP on aerobic mesophilic counts of chicken meat stored for 8 days at $4{ }^{\circ} \mathrm{C}$

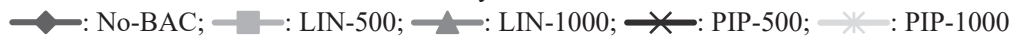

\subsection{Electronic nose analysis}

The E-nose was able to reduce data dimensionality and properly distinguish group treated with BACs and control (Fig. 2: A, B, and C). Overlapping between LIN and PIP groups were noticed, while control yielded considerable mean differences. Reduced TBARS amounts were noticed with both BACs indicating that the instrument can classify the chicken meat as either fresh or spoiled with rancid flavour. It was noted that both BACs, especially LIN, produced spicy odour, this odour was perceived abundantly just after opening the packages, which might provide pleasing flavour attributes to some foods such as meat and increase the acceptance by consumers. ROKAITYTE and co-workers (2016) found that after one day of storage, the minced meat treated with LIN exhibited higher score of flavour and overall acceptability than control. MARTÍNEZ and co-workers (2006) noticed that off-odour formation was significantly delayed in all fresh pork sausages with added black pepper $(\mathrm{P}<0.05)$. Additionally, several factors can support the changes in aroma profile of meat during storage, such as: progress of lipid oxidation, fat content, liberation of fatty acids, and increased microbial load during storage. 
A

Canonical discriminant functions

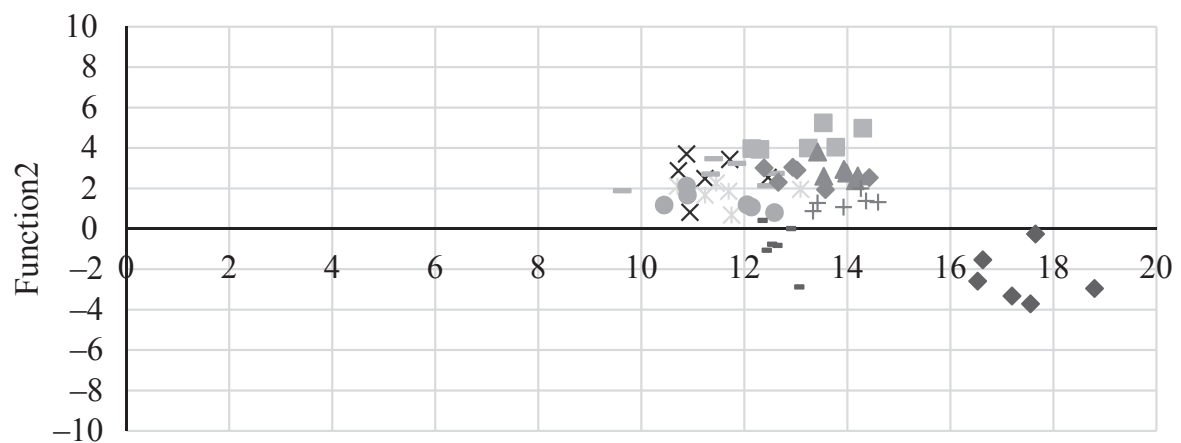

Function1

A: $\diamond:$ No-BACs-day 1; : No-BACS-day 8; $\Delta$ : LIN-500-day 1; X: LIN-1000-day 1; Ж: LIN-500-day 8;

: LIN-1000-day 8; +: PIP-500-day 1; -: PIP-1000-day 1; -: PIP-500-day 8

B

Canonical discriminant functions

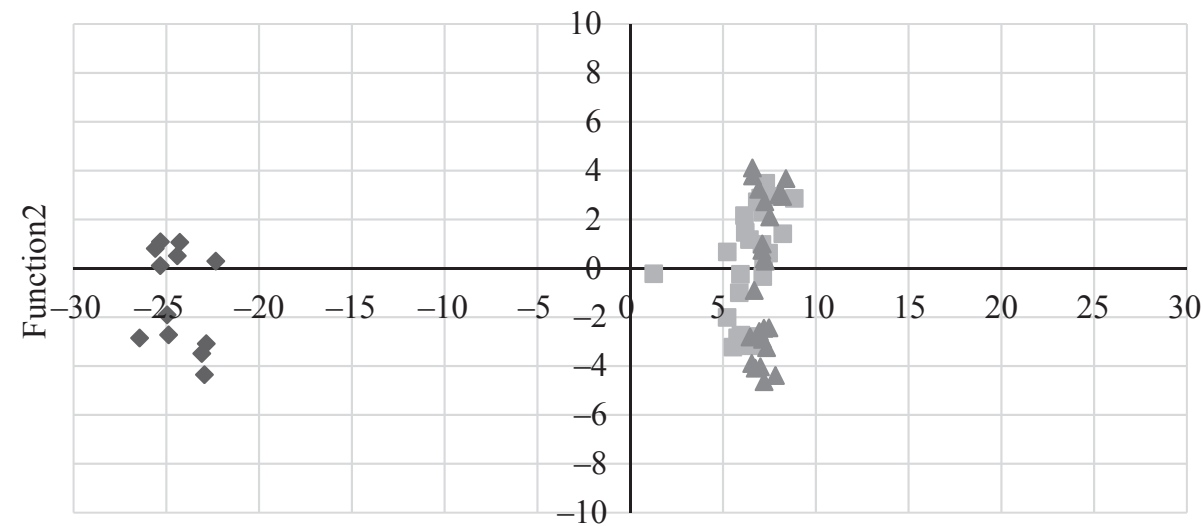

Function1

Fig. 2. Effect of different concentrations of LIN and PIP on smell detection by electronic nose in chicken meat stored for 8 days at $4^{\circ} \mathrm{C}$; (A): The separation based on storage days and concentration of BACs, (B): The separation based on BACs type, and (C): The separation based on concentration of BACs.

B: $\diamond:$ No-BACs; : LIN; $\triangle$ : PIP 


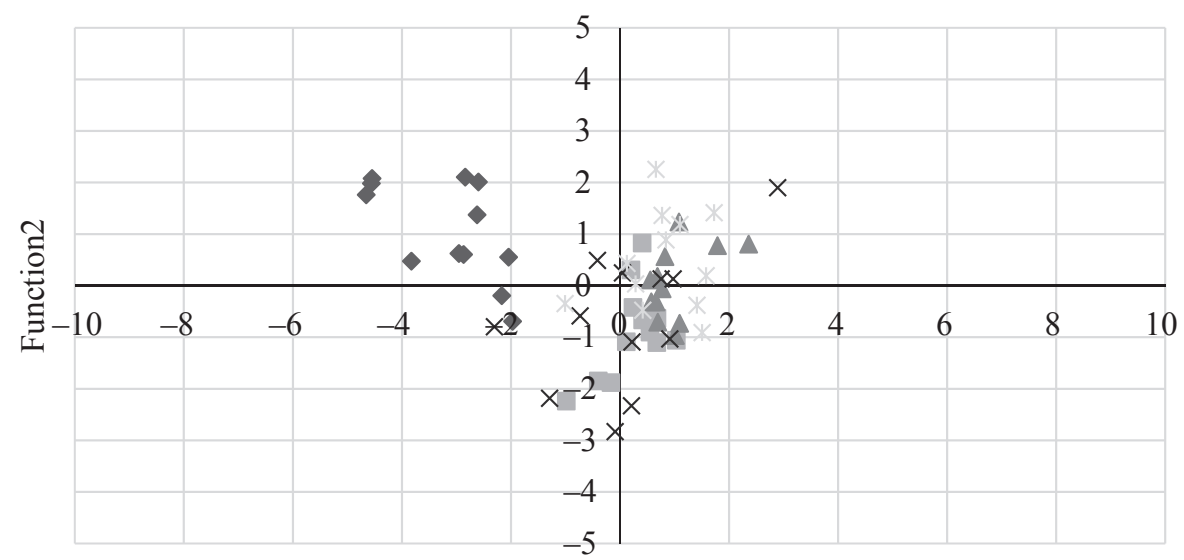

Function1

Fig. 2. Cont.

C: $\diamond:$ No-BACs; ㅍ: LIN-500; $\triangle$ : LIN-1000; X: PIP-500; Ж: PIP-1000

\section{Conclusions}

The addition of LIN and PIP to chicken breast provided a protective effect for colour parameters and nonsignificant reduction in lipid oxidation compared to untreated meat. LIN showed in vitro inhibitory effect against Gram-positive and Gram-negative bacteria except for Pseudomonas lundensis. No inhibition activity was noticed for PIP, but prolongation of the lag phase of the growth of AMC was noticed in PIP treated meat. E-nose was able to classify treated and non-treated samples and detected odour accumulation of BACs in meat. The findings of the present study highlight the potential of LIN and PIP to increase shelf life and to enhance the quality of meat and meat products.

This study is supported by the European Union and co-financed by the European Social Fund (grant agreement no. EFOP-3.6.3.-VEKOP-16-2017-00005).

The authors also would like to thank the laboratory technician colleagues and the Doctoral School of Food SciencesSZIU - Hungary for their support in conducting this research.

\section{References}

Dorman, H.J.D. \& DEANS, S.G. (2000): Antimicrobial agents from plants: antibacterial activity of plant volatile oils. J. Appl. Microbiol., 88, 308-316.

European Commission (2002): (2002/113/EC) Commission Decision of 23 Jan. 2002 amending Commission Decision 1999/217/EC as regards the register of flavouring substances used in or on foodstuffs (Text with EEA relevance) (notified under document number C (2002) 88).

Friedrich, L., Siró, I., DAlmadi, I., HoRvÁTh, K., Ágoston, R. \& BAlla, Cs. (2008): Influence of various preservatives on the quality of minced beef under modified atmosphere at chilled storage. Meat Sci., 79, 332-343. 
Gorgani, L., Mohammadi M., Najafpour, G.D. \& Nikzad, M. (2017): Piperine - the bioactive compound of black pepper: From isolation to medicinal formulations. Comp. Rev. Food Sci. F., 16, 124-140.

Jridi, M., Siala, R., FaKhfaKh, N., Ayadi, M.A., Elhatmi, M., TAKtaK, M.A., NaSri, M. \& Zouari, N. (2015): Effect of rosemary leaves and essential oil on turkey sausage quality. Acta Alimentaria, 44, 534-541.

Karabagias, I., BadeKa, A. \& Kontominas, M.G. (2011): Shelf life extension of lamb meat using thyme or oregano essential oils and modified atmosphere packaging. Meat Sci., 88, 109-116.

KéItA, S.M., Vincent, C., Schmit, J.P. \& BÉlanger, A. (2000): Essential oil composition of Ocimum basilicum L., O. gratissimum L. and O. suave L. in the Republic of Guinea. Flavour Frag. J., 15, 339-341.

Martínez, L., Cilla, I.A., Beltrán, J. \& Roncales, P. (2006): Effect of Capsicum annuum (red sweet and cayenne) and piper nigrum (black and white) pepper powders on the shelf life of fresh pork sausages packaged in modified atmosphere. J. Food Sci., 71, S48-S53.

Mittal, R. \& Gupta, R.L. (2000): In vitro antioxidant activity of piperine. Method. Find. Exp. Clin., 22, $271-274$.

Pattnaik, S., Subramanyam, V.R., Bapaji, M. \& Kole, C.R. (1997): Antibacterial and antifungal activity of aromatic constituents of essential oils. Microbios, 89, 39-46.

Peana, A.T., D’Aquila, P.S., Panin, F., Serra, G., Pippia, P. \& Moretti, M.D. (2002): Anti-inflammatory activity of linalool and linalyl acetate constituents of essential oils. Phytomedicine, 9, 721-726.

Piñon, M.I., Alarcon-Rojo, A.D., Renteria, A.L., Mendez, G. \& Janacua-Vidales, H. (2015): Reduction of microorganisms in marinated poultry breast using oregano essential oil and power ultrasound. Acta Alimentaria, 44, 527-533.

Preedy, V.R. (2015): Essential oils in food preservation, flavor and safety. Academic Press, London. pp. 142-143.

Rokaityte, A., Zaborskiene, G., Macioniene, I., Rokaitis, I. \& Sekmokiene, D. (2016): Combined effect of lactic acid, bioactive components and modified atmosphere packaging on the quality of minced meat. Czech J. Food Sci., 34, 52-60.

Shivarani, S.K., Saxena, N. \& Udaysree, N. (2013): Antimicrobial activity of black pepper (Piper nigrum L.). Global J. Pharmacol., 7, 87-90.

Tarladgis, B.G., Watts, B.M., Younathan, M.T. \& Leroy-Dogan, J. (1960): A distillation method for the quantitative determination of malonaldehyde in rancid foods. J. Am. Oil Chem. Soc., 37, 44-48.

Open Access statement. This is an open-access article distributed under the terms of the Creative Commons Attribution 4.0 International License (https://creativecommons.org/licenses/by/4.0/), which permits unrestricted use, distribution, and reproduction in any medium, provided the original author and source are credited, a link to the $\mathrm{CC}$ License is provided, and changes - if any - are indicated. (SID_1) 